УДК 550.42:550.93:552.321

\title{
ПРИРАЗЛОМНЫЕ ТЕКТОНИТЫ ЕНИСЕЙСКОГО КРЯЖА. СТАТЬЯ 2: P-T-t-d ЭВОЛЮЦИЯ И ГЕОДИНАМИЧЕСКИЕ МОДЕЛИ ФОРМИРОВАНИЯ
}

\author{
И. И. Лиханов ${ }^{1}$, А. А. Крылов ${ }^{1}$, Ж.-Л. Ренье ${ }^{2}$ \\ ${ }^{1}$ Институт геологии и минералогии им. В. С. Соболева СО РАН, Новосибирск \\ ${ }^{2}$ Университет Мугла, Мугла, Турция
}

Поступила в редакцию 28 марта 2018 г.

\begin{abstract}
Аннотация: в пределах Приенисейской региональной сдвиговой зон ы Енисейского кряжа изучены метапелиты и метабазиты, подвергшиеся интенсивным деформациям с перекристаллизацией субстрата и образованием тектонитов. Выявленные различия в Р-Т параметрах метаморфизма между сильно- и слабодеформированными породами и конфигурации P-T-t-d трендов, рассчитанные с использованием минеральной геотермобарометрии и псевдосечений в системе NCKFMASH, обсуждены в рамках геодинамических моделей, контролируемых разными тектоническими механизмами. Полихронный динамометаморфизм гнейсов Ангаро-Канского блока на юге и формирование основной массы бластомилонитов северного сегмента ПРСЗ происходили с повышением давления на 1,5-3 кбар при незначительном увеличении температуры с низким метаморфическим градиентом $d T / d H<10^{\circ} \mathrm{C} /$ км в сравнении с фоновыми значениями более раннего регионального метаморфизма, что вероятно было обусловлено утолщением земной коры в результате быстрого надвига/субдукиии с последуюшим быстрым подъемом пород. Максимальные превышения термодинамических параметров метаморфизма установлены в тектонитах базитового состава с реликтовыми глаукофансланцевыми ассоциациями, которые подверглись метаморфизму с одновременным значительным ростом давления на 3-5 кбар и температуры на 180-240 ${ }^{\circ} \mathrm{C}$ пи более высоком градиенте $d T / d H=15-20^{\circ} \mathrm{C} / \kappa$. Такие превышения P-T параметров могли быть связаны с прогрессивным метаморфизмом, осложненным локальным разогревом пород при вязких деформациях и превышением ориентированного тектонического давления над литостатическим в зонах пластического сдвига. Полученные данные хорошо согласуются с результатами численных экспериментов, что подтверждает представления о роли тектонического стресса как дополнительного термодинамического фактора метаморфических преобразований в шовных зонах земной коры.
\end{abstract}

Ключевые слова: высокобарические тектониты, минеральная геотермобарометрия, псевдосечения, тектонические модели, Енисейский кряж

\section{FAULT TECTONITES OF THE YENISEI RIDGE. Article 2: P-T-t-d EVOLUTION AND POSSIBLE TECTONIC MODELS}

Abstract: metapelites and metabasites subjected to intensive deformations with recrystallization of the substrate and the formation of tectonites have been studied within the Yenisei regional shear zone of the Yenisei Ridge. The revealed differences in P-T metamorphism parameters between strongly and weakly deformed rocks and P-T-t-d trend configurations, calculated using mineral geothermobarometry and pseudosections in the NCKFMASH system, were discussed within geodynamic models controlled by different tectonic mechanisms. The polychronous dynamometamorphism of the gneisses of the Angara-Kan block in the south and the formation of the main mass of the blastomylonites of the northern segment of the YRSZ occurred with an increase in pressure of 1,5-3 kbar with a slight increase in temperature with a low metamorphic gradient $d T / d H<10^{\circ} \mathrm{C} / \mathrm{km}$ in comparison with the background values of the earlier regional metamorphism. This was probably due to the thickening of the earth's crust as a result of rapid thrust/subduction, followed by a rapid rise in the rocks. The maximum excess of the thermodynamic parameters of metamorphism was established in the tectonites of the basite composition with relic glaucophane schist associations that underwent metamorphism with a simultaneous significant increase in pressure by 3-5 kbar and in temperature by 180$240^{\circ} \mathrm{C}$ with a higher gradient $d T / d H=15-20^{\circ} \mathrm{C} / \mathrm{km}$. Such excesses of P-T parameters could be associated with progressive metamorphism, complicated by local heating of rocks under viscous deformations and exceeding the oriented tectonic pressure over lithostatic in the zones of plastic shear. The obtained data are in good agreement with the results of numerical experiments, which confirms the concept of the role of tectonic stress as an additional thermodynamic factor of metamorphic transformations in the suture zones of the Earth's crust.

Key words: high-pressure tectonites, mineral geothermobarometry, pseudo-sections, tectonic models, Yenisei Ridge 


\section{Введение}

Статья направлена на решение одной из актуальных геологических проблем - соотношения деформационных и метаморфических процессов в земной коре и их генетической взаимосвязи. Перспективными объектами для выяснения этих вопросов являются глубинные зоны пластических сдвиговых деформаций. Интерес к этим зонам обусловлен фундаментальными (исследование процессов стрессметаморфизма) и прикладными (связь с этими процессами очагов землетрясений) аспектами.

В научной литературе последних лет особое внимание уделяется окраинно-континентальным сдвиговым зонам - областям объемного хрупко- и вязкопластического течения горных масс, локализованным вдоль узких линейных структур земной коры. Эти зоны являются обязательным элементом структуры орогенных поясов [1-3]. Они встречаются в различных геодинамических обстановках и, как правило, контролируются комплексами орогенных и рифтогенных бластомилонитов [4], значение которых для тектонических реконструкций ранее сильно недооценивалось. Дефицит данных о термодинамических параметрах и времени проявления синсдвиговых деформаций в глубинных зонах земной коры привел к господствующим в литературе представлениям о второстепенном вкладе деформационной компоненты в общую энергетику формирования региональных метаморфических структур [5].

Однако в последнее время выявлена важная роль синсдвиговых метаморфических процессов в формировании структур складчатых поясов, что обусловило приоритетное использование продуктов динамометаморфизма для решения многих петрогенетических проблем. В частности, были детально изучены процессы фрагментации вещества с обособлением реологически контрастных доменов с индивидуальной $P-T$ $t-d$ историей формирования [6,7], выявлены соотношения литостатического и тектонического давления в глубинных зонах пластических сдвиговых деформаций [8-11]. Особенно активно в современной литературе обсуждается роль тектонического стресса как дополнительного фактора метаморфизма в связи с вопросами генерации сверхдавлений в субдукционных и сдвиговых зонах [12]. Прогресс в этом направлении позволил на основе модельных примеров создать современную теоретическую концепцию тектонического давления, определяющую природу сверхдавления и вариаций давления в связи с деформациями пород и их реологическими свойствами [13]. Эти представления были подтверждены результатами численного моделирования баланса сил в развивающемся сдвиговом нарушении [14-18]. Результаты показали, что тектоническое сверхдавление в породах может быть значительно выше, чем девиаторный стресс, отражающий литостатическую нагрузку, что указывает на существование гетерогенного стресса и значительных отклонений давления от литостатического в земной коре.
Тем не менее, несмотря на возрастающий интерес к этой проблеме, природные наблюдения этого явления пока ещё достаточно редки. В этой связи можно упомянуть всего лишь несколько работ [19-28]. В настоящей статье на примере приразломных тектонитов контрастного химического состава Приенисейской региональной сдвиговой зоны (ПРСЗ) приведены петрологические свидетельства таких превышений давления и температуры при интенсивных сдвиговых деформациях в неоднородной среде, что может предполагать тектонический контроль стресс-метаморфизма в шовных зонах земной коры. Результаты геотермобарометрии проинтерпретированы в рамках популярных тектонических моделей. В качестве одной из возможных гипотез тектонической эволюции пород региона рассмотрена модель о превышении тектонического сверхдавления над литостатическим в зоне пластического сдвига, что имеет ключевое значение для реконструкции условий петрогенезиса в глубинных зонах сдвиговых деформаций и для понимания особенностей развития зон перехода палеоокеан-континент.

\section{Краткое резюме предыдущих исследований}

Настоящая работа базируется на эмпирическом материале, опубликованном в прошлом номере журнала [29]. В этой статье нами были изучены метапелиты и метабазиты в пределах Приенисейской региональной сдвиговой зоны Енисейского кряжа, подвергшиеся интенсивным деформациям с перекристаллизацией субстрата и образованием тектонитов. В качестве первого объекта исследования выбраны палеопротерозойские метаморфические породы ЮжноЕнисейского кряжа, распложенные в зоне сочленения канской и енисейской серий. Породы другого объекта на северо-западе Заангарья Енисейского кряжа входят в состав субдукционно-аккреционного комплекса, где встречаются в виде тектонических пластин, линз или блоков в серпентинитовом меланже. Проведенные исследования включали в себя обзор геологических особенностей и основных структурных элементов Енисейского кряжа, а также геологоструктурную и минералого-петрографическую характеристику пород, химические особенности минералов, увязанные с изотопными датировками деформационно-метаморфических преобразований и хронологической последовательностью крупных этапов и событий в геологической истории Енисейского кряжа. При анализе этих данных было показано, что наложение более поздних минеральных ассоциаций на ранние парагенезисы в ходе разных геодинамических событий хорошо коррелируется с геолого-структурными особенностями доменов сильно- и слабодеформированных пород, реакционными микротекстурами, химической зональностью минералов и изотопными датировками. Такие индикаторные признаки свидетельствуют о полиметаморфической истории пород, контролируемой разными тектоническими обстановками и механизмами. В итоге авторы пришли к выводу, что неоднородность метаморфических преобразо- 
ваний и выявленные особенности реологии пород, включающие процессы фрагментации в системе «гнейсы - бластомилониты» и структурно-текстурные особенности бластомилонитов, обусловленные сегрегационным перераспределением материала в условиях регионального сдвига, указывают на возможность генерации сверхдавлений и роста температуры в шовных зонах земной коры. Это предположение требует подтверждения надежными геотермобарометрическими расчетами. Аналитические данные, использованные для геотермобарометрических определений, приведены в табл. 1-3 [29].

Термодинамические условия метаморфизма $\boldsymbol{P}$-T параметры: минеральная геотермобарометрия

Ангаро-Канский блок. $P-T$ параметры метаморфизма Ангаро-Канского блока, вычисленные на основе реальных составов породообразующих минералов и их зональности при совместном использовании взаимосогласованных калибровок и соответствующих моделей смешения для Grt-Bt геотермометра [30] и двух калибровок для Grt-Rt-Ilm-P1-Qz [31] и Grt-Bt-PlQz [32]. Величины P-T параметров метаморфизма пород были рассчитаны при совместном использовании геотермометров и геобарометров в пакете MATHEMATICA 5.0 с помощью процедуры NullSpace [33]. Результаты геотермобарометрии приведены в табл. 1. Ошибки определения $P-T$ параметров при совместном использовании таких геотермометров и геобарометров, рассчитанные с учетом аналитических погрешностей и энтальпии реакций геотермобарометров, не превышают $\pm 30^{\circ} \mathrm{C}$ и $\pm 0,5$ кбар [34], что согласуется с цитируемыми в литературе неточностями геотермобарометров [35].
Таблица 1

Оченки Р-Т условий метаморфизма реликтовых гнейсов и тектонитов Ангаро-Канского блока пород по минеральным геотермобарометрам

\begin{tabular}{|c|c|c|c|c|c|}
\hline & \multicolumn{5}{|c|}{ Реликтовые гнейсы } \\
\hline № обр. & $14-1$ & $14-2$ & $14-8$ & $06-3$ & $06-1$ \\
\hline$T^{\circ}$ С/Ркб & $5,8 / 657$ & $5,6 / 655$ & $6,0 / 651$ & $6,5 / 614$ & $5,7 / 615$ \\
\hline${ }^{*} T^{\circ}$ С/Ркб & $5,9 / 648$ & $5,6 / 640$ & $6,2 / 626$ & $6,5 / 577$ & $5,8 / 572$ \\
\hline & \multicolumn{5}{|c|}{ Тектониты } \\
\hline$T^{\circ}$ С/Ркб & $7,3 / 674$ & $6,8 / 673$ & $7,4 / 664$ & $8,2 / 645$ & $7,3 / 634$ \\
\hline
\end{tabular}

Примечание: $T^{\circ} C / P \kappa б$ и $* T^{\circ} C / P \kappa б-$ значения $P$ - $T$ параметров, полученные при совместном решении Grt-Bt геотермометра [30] и Grt-Bt-P1-Qz геобарометров [32] и Grt-Rut-Ilm$\mathrm{Pl-Qz} \mathrm{[31]} \mathrm{геобарометров,} \mathrm{соответственно.}$

Расчеты показали, что средние значения $P-T$ условий метаморфизма, вычисленные в разных доменах (5,9 кбар $/ 635^{\circ} \mathrm{C}$ - исходные породы; 7,4 кбар/660 ${ }^{\circ} \mathrm{C}-$ бластомилониты), имеют значимые различия по давлению в пределах ошибок метода (рис. 1). Таким образом, наложенные сдвиговые деформации могли привести к локальному обособлению реологически контрастных доменов в зонах тектонитов, где исходные породы подверглись динамометаморфизму с повышением давления на 1,4-1,7 кбар при незначительном повышении температуры на $20-30^{\circ} \mathrm{C}$ (табл. 1; рис. 1). Низкие величины метаморфического градиента $\left(\mathrm{dT} / \mathrm{dH}<10^{\circ} \mathrm{C} /\right.$ км) и слабое развитие температурной зональности в коллизионных комплексах связывают с относительной кратковременностью событий и тепловой инерцией относительно давления [36]. Близкие соотношения между миналами гранатов различных генераций и аналогичная ситуация в отношении $P-T$ параметров метаморфизма характерны для надвиговых

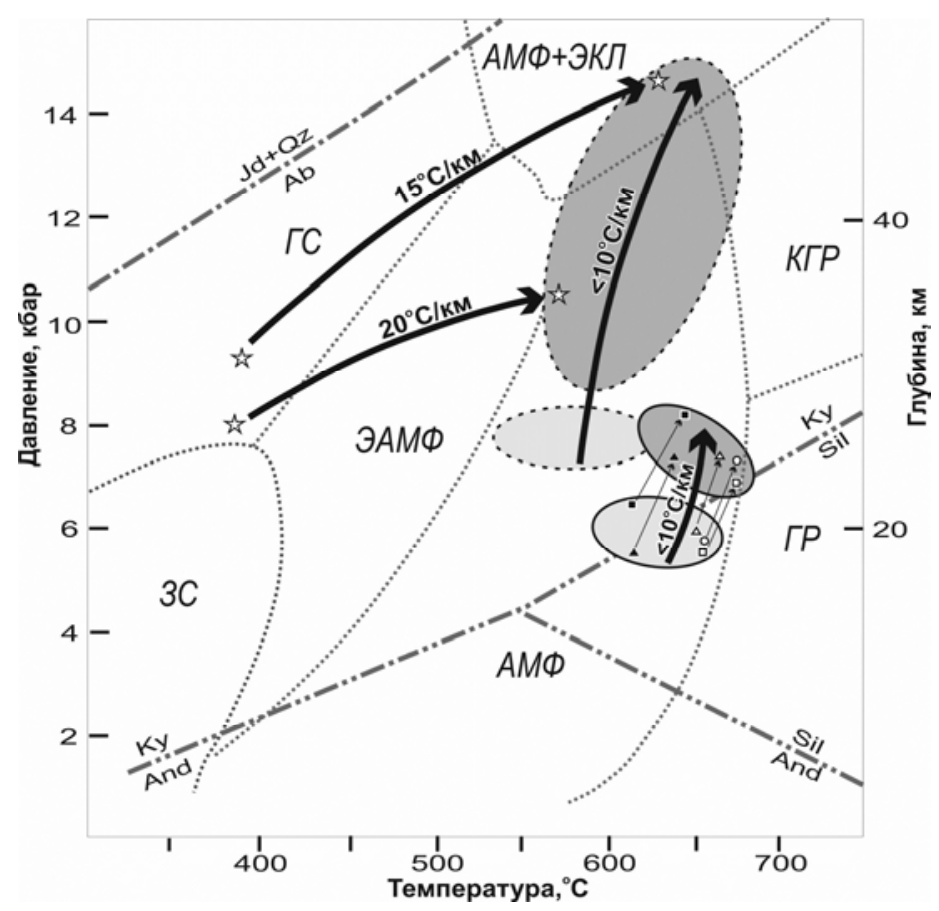

Puc. 1. Р-T условия и $P-T$ тренды эволюции метаморфизма для исходных пород и тектонитов ПРСЗ. Эллипсы светло-серого и темно-серого цветов обозначают $P$ - $T$ области исходных гнейсов и развитых по ним бластомилонитов, соответственно. $P$ - $T$ поля пород Ангаро-Канского блока и Заангарья оконтурены, соответственно, сплошной и пунктирной линиями. Обобщенные направления $P-T$ трендов эволюции стресс-метаморфизма показаны толстыми стрелками со значениями метаморфического градиента. Тонкими стрелками показаны локальные вариации $P-T$ параметров между реликтовыми гнейсами и тектонитами в разных доменах пород Ангаро-Канского блока. Серые штрихпунктирные линии - положение моновариантных равновесий полиморфов $\mathrm{Al}_{2} \mathrm{SiO}_{5}$ и равновесия альбит=жадеит+кварц. Точечные линии - границы метаморфических фаций для метабазитовой системы [81], где зеленые сланцы (3С), голубые сланцы (ГС), эпидотовые амфиболиты (ЭАМФ), амфиболиты (АМФ), гранулиты (ГР), кианитовые гранулиты (КГР) и эклогиты (ЭКЛ). 
областей Новой Англии в США [37], провинции Мойн в Шотландии [38], и Северо-Енисейского кряжа [39], отличающихся низким метаморфическим градиентом. Выявленные различия в $P-T$ параметрах метаморфизма для разных доменов пород и генераций граната согласуются с результатами численного моделирования $[11,14,15]$ о превышении тектонического сверхдавления над литостатическим в зоне пластического сдвига на уровне верхней и средней коры.

Заангарье. Расчет $P$ - T условий формирования пород метапелитового состава выполнен с помощью процедур и набора геотермобарометров, применяемых для оценки параметров метаморфизма пород АнгароКанского блока. Для метабазитов эти данные получены с использованием калибровки и соответствующих моделей состав-активность для Amp-Pl геотермометра [40] и Grt-Amp-Pl геобарометра [41]. Для независимого контроля $P-T$ параметров эти значения сопоставлялись с оценками давлений и температур, полученных с помощью фенгитового [42], Grt-Amp-Pl-Qz геобарометров [43] и двух эмпирических Na-Ca Amp-Pl [44] и $\mathrm{Na}-\mathrm{Ca}$ Amp-Pl-Chl-Ep-Qz [45] геотермобарометров. Для оценки достоверности результатов геотермобарометрии эти значения, с учетом точности определений, сопоставлялись с таковыми $P-T$ условий, полученных при использовании компьютерной программы THERMOCALC 3.2 [46], базирующейся на согласованных базах термодинамических данных для миналов [47]. Расчеты активностей миналов для THERMOCALC проводились с помощью программы АХ2 [46]. Результаты минеральной геотермобарометрии, согласующиеся с расчетами по программе THERMOCALC, приведены в табл. 2 и на рис. 1. Расчеты показали значимые различия параметров метаморфизма для различных генераций пород в пределах погрешности методов. $P$ - $T$ параметры допиковой ассоциации, вычисленные по составам фаз-включений и контактирующего с ними граната, оцениваются в 7,5-8 кбар $/ 380-420^{\circ} \mathrm{C}$ для обр. 11 и 9-10 кбар $/ 385-430^{\circ} \mathrm{C}$ для обр. 3 (рис. 1). Эти оценки соответствует условиям формирования глаукофановых сланцев на петрогенетической решетке для метабазитов железистого состава [48]. Отсутствие во включениях метаморфической роговой обманки, олигоклаза и Na-пироксена указывает на то, что температуры метаморфизма не превышали $450^{\circ} \mathrm{C}$ при давлении менее 9-10 кбар [49]. Кульминационные термодинамические условия в тектонитах шовной зоны определялись температурой $10-11$ кбар $/ 550-570^{\circ} \mathrm{C}$ для обр. 11 и 14 15 кбар $/ 620-640^{\circ} \mathrm{C}$ для обр. 3 (табл. 2 ; рис. 1), что свидетельствует о наложении более высокотемпературных и высокобарических минеральных ассоциаций на ранние парагенезисы в сдвиговых зонах. Отсутствие глаукофана в пиковом парагенезисе объясняется его замещением роговой обманкой в ходе динамометаморфизма при температуре около $500^{\circ} \mathrm{C}[50]$.

\section{$\boldsymbol{P}-\boldsymbol{T}$ тренды метаморфизма и $\boldsymbol{P}-\boldsymbol{T}$ - $\boldsymbol{X}$ псевдосечения}

Чтобы уточнить Р-Т параметры, которые преобладали при образовании метабазитов 11 и 3, наблюдае- мые минеральные ассоциации и составы минералов сравнивались со стабильностью полей и составом фаз (т.е. с минеральными изоплетами) в псевдосечениях P-T-X. В отличие от обобщенных петрогенетических решеток, такие диаграммы-псевдосечения отображают реальные устойчивые минеральные ассоциации для специфического химического состава породы в определенном $P-T$ диапазоне [51]. При построении псевдосечений оригинальный валовый состав пород $[52,53]$ был модифицирован, чтобы компенсировать содержание $\mathrm{FeO}$ в ильмените, в предположении, что ильменит является основной $\mathrm{TiO}_{2}$-содержащей фазой (проекция из точки ильменита). Содержания $\mathrm{Fe}_{2} \mathrm{O}_{3}$ и $\mathrm{MnO}$ не учитывались, что, вероятно, могло повлиять на стабильность эпидота, глаукофана, роговой обманки, омфацита и граната. Карбонаты в шлифах редки, что подразумевает существенно водный состав флюида.

Псевдосечения были рассчитаны с помощью программы THERMOCALC 3.33 [54] и внутренне согласованной термодинамической базы данных в версии 5.5 [55] для системы $\mathrm{Na}_{2} \mathrm{O}-\mathrm{CaO}-\mathrm{K}_{2} \mathrm{O}-\mathrm{FeO}-\mathrm{MgO}-\mathrm{Al}_{2} \mathrm{O}_{3}-\mathrm{SiO}_{2}-$ $\mathrm{H}_{2} \mathrm{O}$ (NCKFMASH). Файлы, отвечающие за соотношение используемых в расчетах активности и состава минералов, включают амфиболовую [56], клинопироксеновую [57] и плагиоклазовую [58] модели. Для граната, хлорита и мусковита модели смешения взяты, соответственно, из работ $[59,60,61]$. В дополнение к вышеназванным твердым растворам минералов в расчетах также использовались чистые фазы: альбит, клиноцоизит (эпидот), лавсонит, кварц и водный флюид $\left(\mathrm{H}_{2} \mathrm{O}\right)$. Предполагалось, что мусковит и вода присутствуют в избытке, а мусковит является единственной фазой, содержащей $\mathrm{K}_{2} \mathrm{O}$ (например, [62]).

Установлено, что наблюдаемая ассоциация гранат + роговая обманка + актинолит + хлорит + эпидот + мусковит + кварц в матриксе обоих образцов стабильна при температуре $500-550^{\circ} \mathrm{C}$ и давлении $12-14$ кбар для обр. 11 и $550-600^{\circ} \mathrm{C}$ и 12-15 кбар для обр. 3 (дивариантное поле hb-act-chl-g-cz-q на pис. $2 a, b$ ). Область $P-T$ параметров для пиковой ассоциации сравнительно хорошо определяется по отсутствию клинопироксена и появлению граната. Однако фенгитовое замещение мусковита, как в матриксе, так и во включениях в гранате, не может быть отнесено к пиковой минеральной ассоциации (рис. $2 a, b$ ). Это указывает на более высокое давление, при котором будет стабилен клинопироксен, глаукофан или лавсонит. Обычно это связывается с инфильтрацией обогащенного $\mathrm{CO}_{2}$ флюида при метаморфизме, понижающего активность воды и сдвигающего кремниевую изоплету фенгита в сторону более высоких давлений и более низких температур [42]. На рис. 3 показаны псевдосечения для образцов 11 и 3 , оконтуренные изоплетами актинолита, роговой обманки, граната и глаукофана.

Для актинолита и роговой обманки в матриксе изоплеты четко пересекаются при давлении 12-14 кбар и температуре $550-600{ }^{\circ} \mathrm{C}$ внутри или вблизи дивариантного поля hb-act-chl-g-cz-q, однако соотношение $\mathrm{Fe}^{\text {tot }} /\left(\mathrm{Fe}^{\text {tot }}+\mathrm{Mg}\right)$ в роговой обманке $(\mathrm{x}(\mathrm{hb}))$ ниже 
䈍

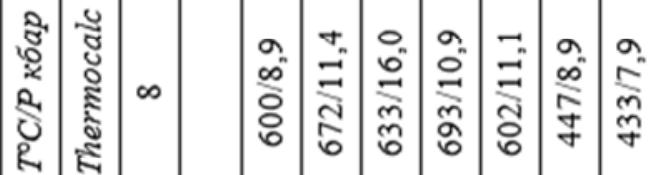

$\stackrel{3}{3}$

ชี.

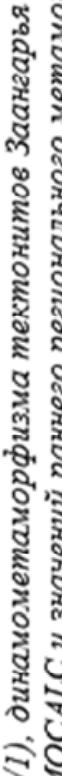

:

离

रे 荡

空

西

8.

वृ

डิ

री डิ

$\approx$

$\approx$

ले

\&

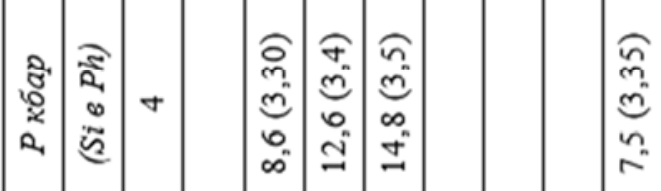

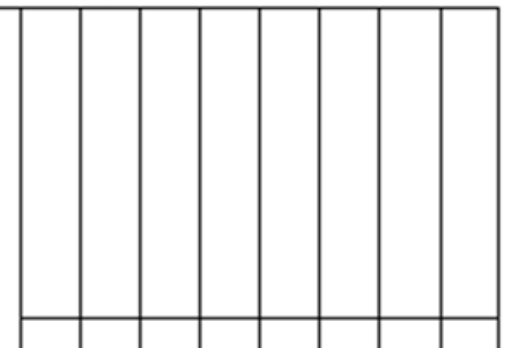

客

공

క్ :

.

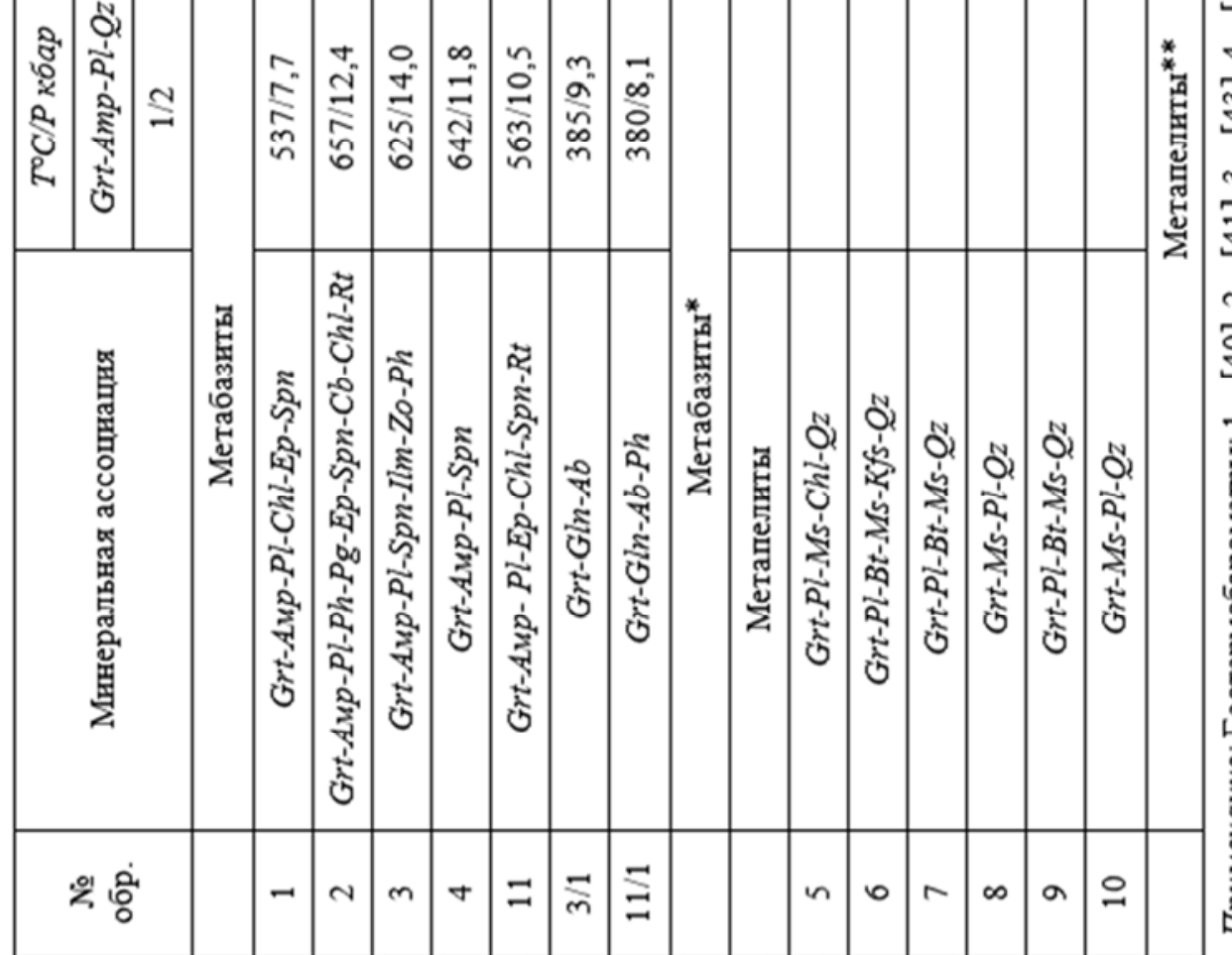

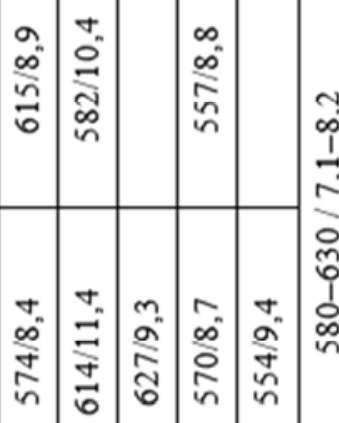

今.

2. 崖

宦

్ㅗㄹ

总

월 앨.

学 일

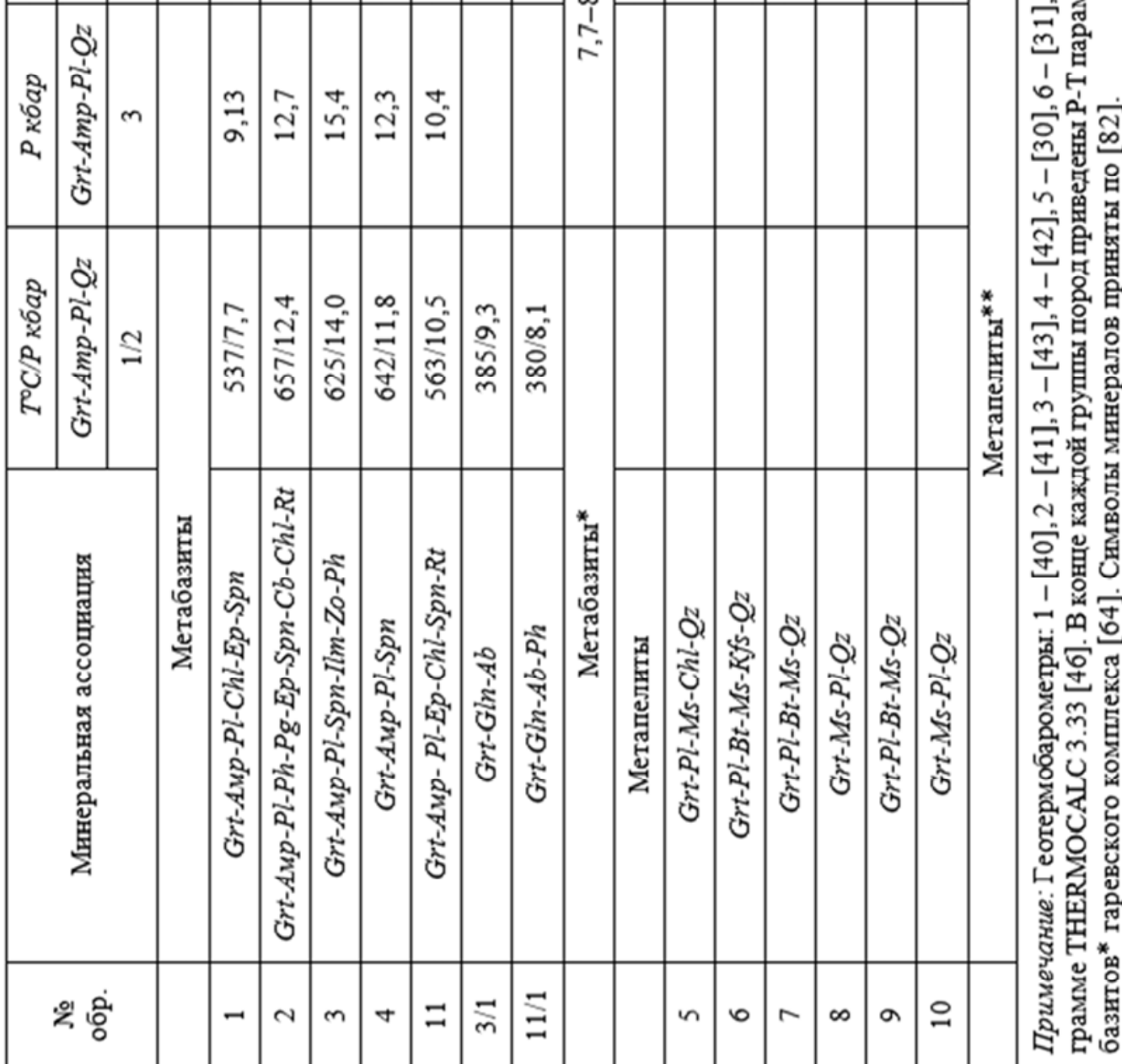


a)

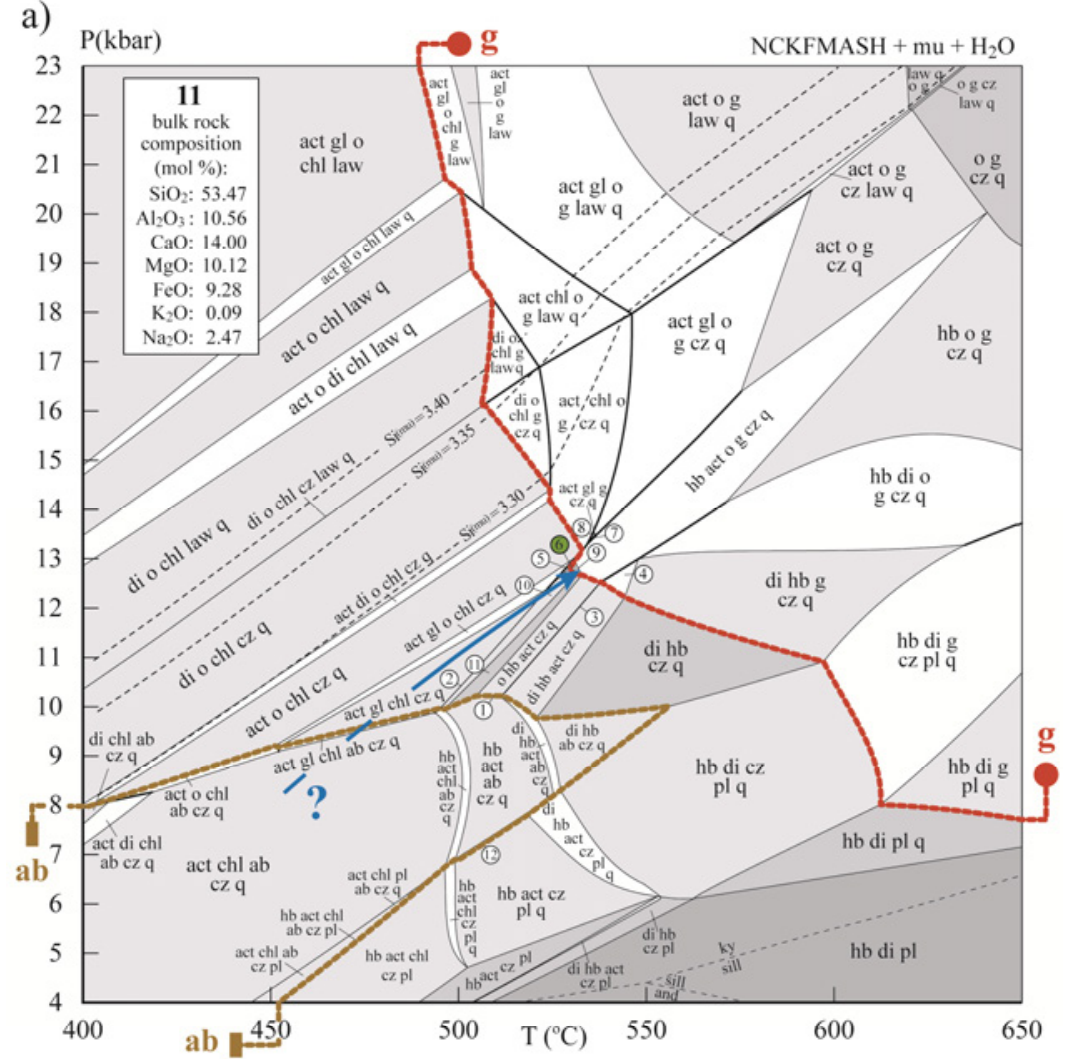
(1) hb act o ab cz q
(2) hb act gl chl cz q
(3) di o hb act cz q
(4) di hb act g cz q
(5) hb act o chl cz q
(6) hb act chl g cz q
(7) hb act gl g cz q
(9) hb act g cz q
(10) hb act chl cz q
(11) hb act cz q
(8) act gl chl g cz q

b)

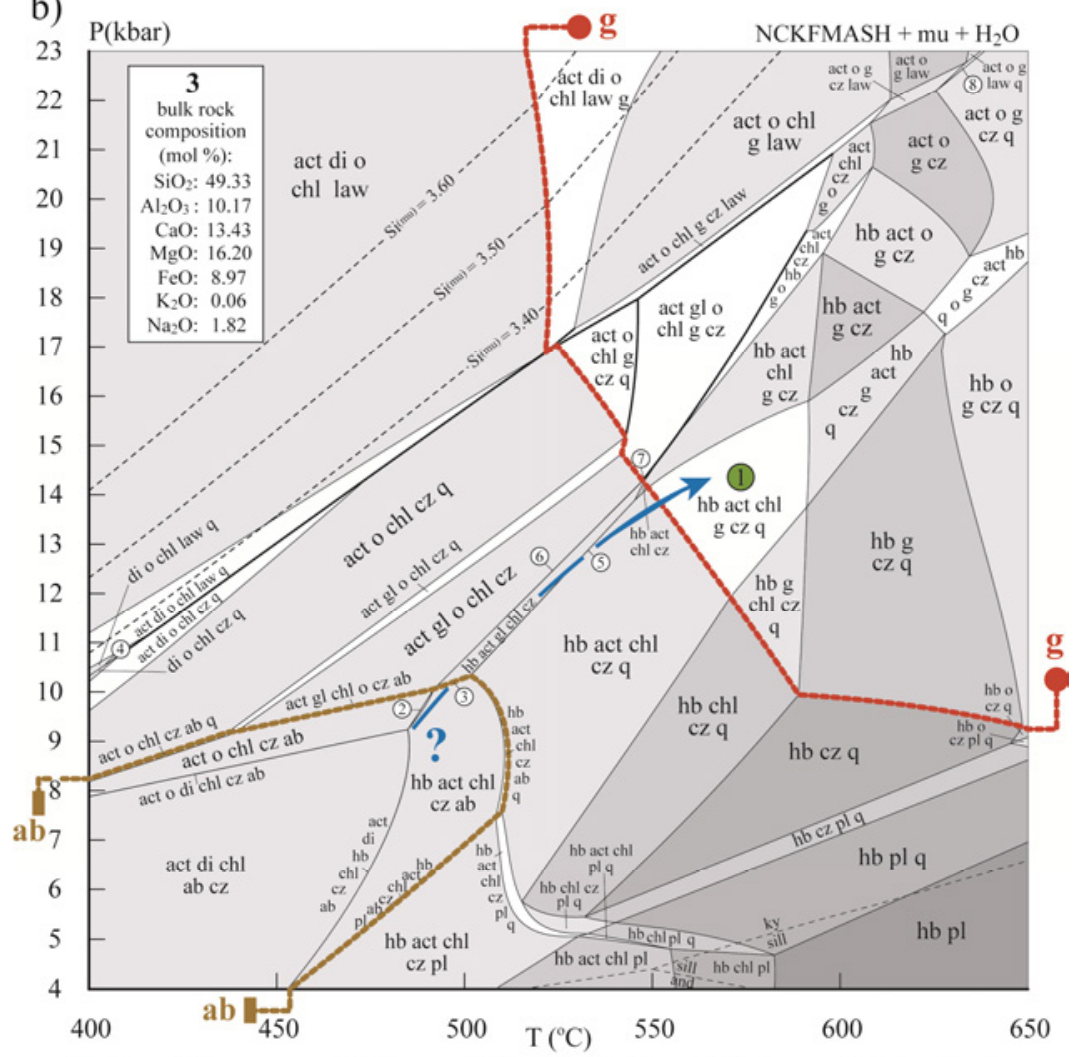

(1) hb act chl g cz q

(2) hb act o chl abcz (3) hb act gl chl abcz

(4) di o chl cz law q

(5) hb act gl chl cz q

(6) hb act gl o chl cz

(7) hb act gl g chl cz

(4) di o chl cz law q
act o g cz law q наблюдаемого в образцах. При этом область $P-T$ параметров не может быть отделена от изоплет граната, которые обычно пересекаются при более высоком давлении, чем ожидалось при данных значениях $\mathrm{X}_{\mathrm{Ca}}$ в гранате $(0,23-0,32)$. Изоплеты глаукофана, встречающегося в виде включений в гранате, обладают несколько более низкими значениями $\mathrm{XAl}(\mathrm{M} 2)$ и $\mathrm{Fe}^{\mathrm{tot}} /\left(\mathrm{Fe}^{\mathrm{tot}}+\mathrm{Mg}\right)$, чем те, которые рассчитаны в псевдосечениях. Стабилизация титанита и других оксидов наряду с понижением активности воды может быть причиной отсутствия равновесия между гранатом и включениями глаукофана и амфиболами матрикса.

Результаты, полученные при помощи псевдосечений и изоплет, предполагают пиковые параметры метаморфизма приразломных метабазитов, равные $12-15$ кбар и $550-600^{\circ} \mathrm{C}$, что характерно для «роговообманковых эклогитов» по классификации [63]. $P$ - $T$ тренд несколько менее четко определен из-за явного несоответствия между наблюдаемыми и рассчитанными изоплетами граната и глаукофана. Тем не менее, отсутствие клинопироксена и наличие альбита в основной массе породы или в качестве включений в гранате предполагают проградный метаморфизм из области стабильности альбита вплоть до дивариантного поля hb-act-chl-g-cz-q, где становится устойчивым гранат. Установленный $P$ - $T$ тренд эволюции с движением «по часовой стрелке» (рис. 2) допускает наличие включений глаукофана, альбита, эпидота и хлорита или мусковита в гранате. $P$ - $T$ параметры, вычисленные при помощи псевдосечений (рис. 2) и с использованием

Puc. 2. Р-Т псевдосечения образцов 11 (а) и 3 (б) в системе NCKFMASH (+ $\left.\mathrm{mu}+\mathrm{H}_{2} \mathrm{O}\right) . P-T$ псевдосечения наблюдаемой пиковой ассоциации hb-act-chl-g-cz-q $\left(+\mathrm{mu}+\mathrm{H}_{2} \mathrm{O}\right) . P-T$ условия наблюдаемой пиковой ассоциации hb-act-chl-g-cz-q (+mu $+\mathrm{H}_{2} \mathrm{O}$ ) составляют около 12-14 кбар и $500-550{ }^{\circ} \mathrm{C}$ для образца 11 и $12-15$ кбар и $550-600^{\circ} \mathrm{C}$ для образца 3. Отсутствие клинопироксена и наличие альбита в виде включений в гранате или в матриксе указывает на проградный метаморфизм от области стабильности альбита к дивариантной зоне hb-act-chl-g-cz-q, в которой становится стабильным гранат. 

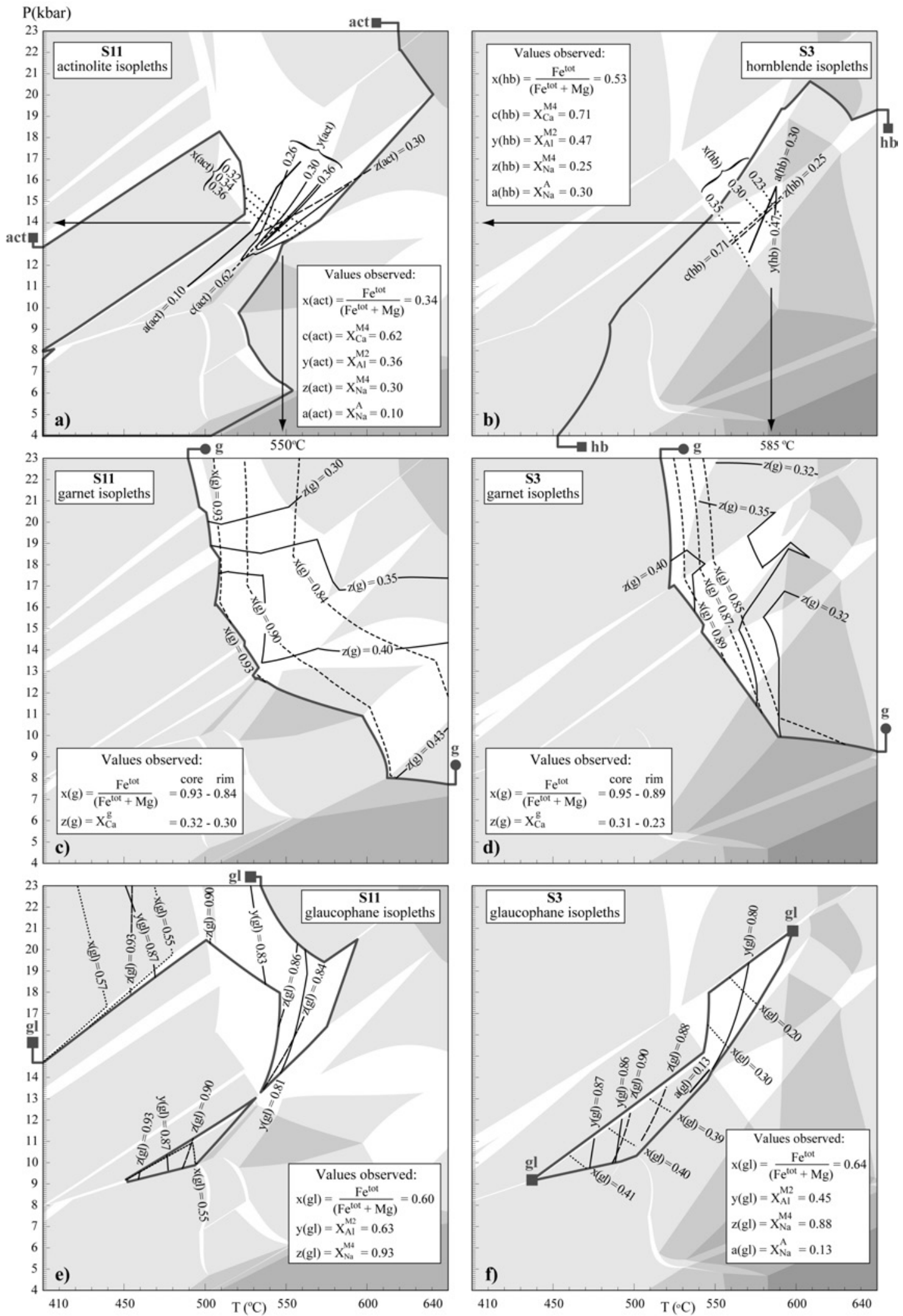

Pис. 3. Наблюдаемые и вычисленные минеральные изоплеты для образцов 11 и 3. Псевдосечения на рисунке оконтурены изоплетами актинолита, роговой обманки, граната и глаукофана. (а-б) Минеральные изоплеты для амфиболов в матриксе (актинолит и роговая обманка) пересекаются близко или внутри дивариантной области hb-act-chl-g-cz-q $\left(+\mathrm{mu}+\mathrm{H}_{2} \mathrm{O}\right)$. Соотношение $\mathrm{Fe}_{\text {tot }} /\left(\mathrm{Fe}_{\mathrm{tot}}+\mathrm{Mg}\right)$ ниже, чем наблюдаемое для роговой обманки в обр. 3. (в-г) Гранатовые изоплеты пересекаются при более высоком давлении и не могут быть отнесены к области $P-T$ параметров пиковой ассоциации. (д-е) Изоплеты глаукофана, представленного включениями в гранате, показывают более низкие значения XAl(M2) и $\mathrm{Fe}_{\text {tot }} /\left(\mathrm{Fe}_{\mathrm{tot}}+\mathrm{Mg}\right)$ по сравнения с теми, что получаются на псевдосечениях. 
зованием методов минеральной геотермобарометрии (рис. 1), в целом хорошо согласуются между собой. Bce $P$ - $T$ тренды имеют почти одинаковые наклоны для проградного участка метаморфизма и отличаются, главным образом, длиной $P-T$ траектории эволюции метаморфизма.

\section{Интерпретация р-т эволюции пород: возможные тектонические модели}

Результаты геотермобарометрии, полученные методами мультиравновесной геотермобарометрии и фазовых диаграмм, показали видимые различия по $P$ $T$ параметрам формирования тектонитов шовной зоны, что свидетельствует о существенной неоднородности и контрастности проявления деформаций по простиранию и вкрест простирания ПРСЗ. В целом, формирование основной массы бластомилонитов происходило с повышением давления в среднем на 23 кбар при незначительном повышении температуры (рис. 1, 2). Более интенсивно деформированные тектониты, приуроченные, как правило, к приразломным зонам или полосам концентрированных деформаций, показывают повышенные значения величин давления (10-15 кбар в метабазитах и 8-13 кбар в метапелитах) в сравнении с фоновыми (литостатическими) значениями более раннего регионального метаморфизма (6-8 кбар), определенными для менее деформируемых участков гаревского комплекса [64].

Максимальные превышения давления (до 5 кбар) отмечены в породах метабазит-ультрабазитового блока (обр. 3), залегающих внутри зоны серпентинитового меланжа на границе Сибирского кратона и Исаковского островодужного террейна. Интенсивная деформация пород приводила к практически полной перекристаллизацией субстрата и образованию новых высокобарических минеральных парагенезисов в условиях фации амфиболовых эклогитов (рис. 1). Поэтому отчетливая запись ранних процессов формирования глаукофановых сланцев была стёрта и сохранилась только в виде реликтовых включений в минералах поздних метаморфических этапов. Формирование этих бластомилонитов в ходе наложенных интенсивных сдвиговых деформаций происходило с максимальным повышением давления на 3-5 кбар с одновременным ростом температуры на $180-240^{\circ} \mathrm{C}$. Генерации таких повышенных термодинамических параметров могли быть связаны с простым прогрессивным увеличением $P-T$ параметров в ходе контролируемой деформацией перекристаллизации вещества, что хорошо согласуется с вычисленной траекторией эволюции $P-T$ параметров пород с ходом «по часовой стрелке». Подобный механизм хорошо объясняет наблюдаемые микротекстурные и химические особенности изученных пород. Дополнительным источником тепла для проградного метаморфизма мог служить локальный разогрев пород (viscous heating) при вязких деформациях $[8,9]$.

Однако формирование основной массы изученных бластомилонитов происходило с повышением давле- ния в среднем на 2-3 кбар при незначительном повышении температуры в сравнении с фоновыми значениями более раннего регионального метаморфизма (табл. 2). Возможно несколько вариантов тектонического развития таких комплексов. Рассмотрим их применение к нашему случаю.

(1) Допустим, что в строении региона принимали участие первоначально горизонтально- или наклонно залегающие метаморфические породы, в последствие деформированные в процессе складчатости и сохранившиеся либо как крыло складки, либо в виде моноклинали. Тогда в своей восточной части они слагали бы ядро складки или наиболее погруженную часть моноклинали. Результаты геотермобарометрии свидетельствуют о перепаде давления в 2-3 кбар, что находится в противоречии с величиной литостатического давления при нормальном погружении, которое возникло бы в этих породах при градиенте 1 кбар/3,5 км. Кроме того, при погружении пород в этом случае происходило бы повышение температуры, как минимум, на $100-120^{\circ} \mathrm{C}$, если принять температурный градиент в $20^{\circ} \mathrm{C} /$ км.

(2) Увеличение давления в зоне сдвига могло быть обусловлено дифференциальным движением блоков земной коры, которые последовательно подвергались эксгумации с различной глубины (например, [65]). Однако эта модель «последовательного структурного сдвига» не имеет в данном случае таких геологических свидетельств, как тектонические контакты и высокие латеральные градиенты температуры между соседними породами.

(3) Увеличение литостатического давления происходило под действием интрузивного тела (магматической «нагрузки»). В этом случае должно иметь место значительное повышение температуры пород за счет тепла кристаллизации магмы (типичные величины для скрытой теплоты кристаллизации на порядки превосходят величины теплогенерации за счет радиоактивных источников) [66], что не согласуется с результатами геотермобарометрии. Вышеупомянутые модели противоречат геологическим и петрологическим наблюдениям, поэтому они должны быть отвергнуты.

Исходя из результатов геотермобарометрии и вычисленных $P$ - $T$ трендов эволюции поздний этап метаморфизма не сопровождался существенным увеличением температуры и происходил в условиях очень низкого геотермического градиента $\left(d T / d H<10^{\circ} \mathrm{C} /\right.$ км$)$. Поэтому необходимо обсудить такой механизм, при котором рост давления происходил в условиях приближающихся к изотермическим. Это возможно при быстром надвиге/поддвиге блоков при коллизии с последующей быстрой эксгумацией пород [67-70]. В соответствии с моделью тектонического утолщения земной коры в результате тепловой инерции температура погруженных на глубину пород не успевает повыситься до равновесной, прежде чем она оказывается поднятой к поверхности. В этом случае продолжительность пост-коллизионной эксгумации обычно не 
превышает 15-20 млн лет, что соответствует быстрой скорости подъема метаморфических пород около 500-700 м/млн лет [71]. Эти значения хорошо согласуются со скоростью эксгумации (400 м/млн лет), рассчитанной для коллизионных метаморфических комплексов Заангарья Енисейского кряжа, по результатам термомеханического численного моделирования [36, 39, 72]. В соответствии с другими известными теплофизическими моделями $[73,74]$ также было показано, что породы нижней плиты приразломной структуры могут подвергаться изотермическому погружению только при повышенной скорости надвига верхней плиты: порядка нескольких сотен метров за миллион лет.

При тектонической интерпретации отдельных надвиговых структур Новой Англии в США Фрэнк Спир с соавторами [37] продемонстрировали, что изотермическое погружение могло происходить в средней плите, расположенной между нижней и верхней плитами, если движение по разломам происходило одновременно. Температуры в данной плите при этом остаются относительно постоянными, так как прогрев сверху уравновешивается остыванием снизу. Однако для применения этой модели к рассматриваемому случаю необходимо, чтобы под континентальной плитой находились аллохтонные породы, разделенные еще одним разломом, что противоречит геологической ситуации в регионе. Также несостоятельна для интерпретации метаморфической эволюции региона модель субизотермического увеличения давления при быстром надвиге блоков пород с различными теплофизическими и теплогенерирующими свойствами, используемая применительно к коллизионному метаморфизму вблизи надвигов [36].

Так как большинство из приведенных выше моделей не подкреплены геологическими и структурными наблюдениями для изученных пород, мы рассматриваем альтернативный механизм, включающий значительные превышения давления, а не постепенный градиент давления от поверхности к глубине. Имеющиеся оценки отклонения давления от литостатического, т.е. наличие избыточного тектонического давления из-за девиаторного напряжения и деформации, указывают на распространенность подобных явлений в различных временных и пространственных масштабах при метаморфизме и процессах литосферной тектоники, включая столкновение плит [10 и ссылки в ней].

В рассмотренных случаях величины избыточного давления могут сильно изменяться и достигать до 100 \% от величины литостатического давления [27], в зависимости от реологии и природы деформированных пород. Реологическая гетерогенность деформирующихся блоков имеет тенденцию усиливать избыточное давление (например, [17]), что наиболее характерно в реологически жестких (сухих) деформированных блоках горных пород мантийной литосферы [75, 76]. Однако есть свидетельства, что и небольшие локальные девиаторные напряжения могут также способствовать генерации сверхдавлений в бластомило- нитах $[27,77]$. Таким образом, влияние значительного избыточного тектонического давления не может быть исключено для тектонитов деформационных зон априори, но должно быть проверено путем изучения реалистичных термомеханических моделей для разных тектоно-метаморфических сценариев.

Наши расчеты показывают, что оценки $P-T$ параметров значительно различаются между тектонитами непосредственно внутри ПРСЗ и менее деформированными породами на удалении от ПРСЗ (табл. 2, рис. 1) в пределах аналитической погрешности [78, 79]. Подобные вариации давления могли быть вызваны интенсивной сдвиговой деформацией в неоднородной среде, что предполагает тектонический контроль поздней стадии метаморфизма. Полученные в настоящей работе результаты согласуются с численными экспериментами, согласно которым ориентированное тектоническое давление, генерированное локально в зонах пластического сдвига, в 1,4-2 раза превышало литостатическое давление $[14,15,17,80]$. Однако, такие расчеты требуют дополнительных исследований и более строгих статистических обоснований в отношении, например, интерпретации $P-T$ профилей через интенсивно- и слабодеформированные толщи и горизонты. Часто диапазоны $P$ - $T$ параметров для пород различных метаморфических этапов могут частично или полностью перекрываться, что создает препятствия для тестирования вышеуказанных моделей.

В целом, привлекаемая нами модель о превышении тектонического сверхдавления над литостатическим в зоне пластического сдвига рассматривается как одна из возможных гипотез тектонической эволюции пород региона наряду с другими известными механизмами, такими как проградное увеличение $P-T$ параметров при вызванной деформацией рекристаллизации, присутствие в тектоническом меланже различных блоков пород с различной метаморфической историей, и пр.

\section{Заключение}

В пределах Приенисейской региональной сдвиговой зоны (ПРСЗ) Енисейского кряжа изучены метапелиты и метабазиты, подвергшиеся интенсивным деформациям с перекристаллизацией субстрата и образованием тектонитов. На основании геолого-структурных и петрологических исследований, выполненных с использованием минеральной геотермобарометрии и псевдосечений в системе NCKFMASH, установлена пространственная связь и корреляция вариаций $P-T$ условий метаморфизма с интенсивностью деформаций пород, что свидетельствуют о неоднородности распределения этих параметров в пределах ПРСЗ. Полихронный динамометаморфизм гнейсов Ангаро-Канского блока на юге и формирование основной массы бластомилонитов северного сегмента ПРСЗ происходили с повышением давления на 1,5-3 кбар при незначительном увеличении температуры с низким метаморфическим градиентом $d T / d H$ $<10^{\circ} \mathrm{C} /$ км в сравнении с фоновыми значениями более 
раннего регионального метаморфизма, что вероятно было обусловлено утолщением земной коры в результате быстрого надвига/субдукции с последующим быстрым подъемом пород. Максимальные превышения термодинамических параметров метаморфизма наблюдаются в тектонитах базитового состава с реликтовыми глаукофансланцевыми ассоциациями, которые подверглись метаморфизму с одновременным значительным ростом давления на 3-5 кбар и температуры на $180-240^{\circ} \mathrm{C}$ при более высоком градиенте $d T / d H=15-20^{\circ} \mathrm{C} /$ км. Такие превышения Р-Т параметров могли быть также связаны с прогрессивным метаморфизмом от условий глаукофансланцевой фации до фации амфиболовых эклогитов, осложненным локальным разогревом пород при вязких деформациях и превышением ориентированного тектонического давления над литостатическим в зонах пластического сдвига. Полученные данные хорошо согласуются с результатами численных экспериментов, что подтверждает представления о возможности генерации сверхдавлений и повышения температуры при интенсивных сдвиговых деформациях в шовных зонах земной коры.

Исследования проведень в рамках выполнения проектов РФФИ № 18-05-00152 и 18-35-00185.

\section{ЛИТЕРАТУРА}

1. Passchier, C. W. Microtectonics / C. W. Passchier, R. A. J. Trouw // Springer-Verlag, Berlin, Heidelberg, 2nd ed. - 2005. $366 \mathrm{p}$.

2. Thermal interaction of middle and upper crust during gneiss dome formation: example from the Montagne Noire (French Massif Central) / K. Fréville [et al.] // J. Metamorph. Geol. 2016. - V. 34. - P. 447-462.

3. Régnier, J.-L. Metamorphism of Precambrian-Paleozoic schists of the Menderes core series and contact relationschips with Proterozoic orthogneisses of the western cine massif, Anatolide belt, western Turkey / J.-L. Régnier, J. E. Mezger, C. W. Passchier // Geol. Mag. - 2007. - V. 144. - P. 67-104.

4. Иванов, С. Н. Континентальный рифтовый метаморфизм / С. Н. Иванов, А. И. Русин // Геотектоника. - 1997. - № 1. C. 6-19.

5. Tajchmanova, L. Pressure variations in metamorphic rocks: Implications for the interpretation of petrographic observations / L. Tajcmanova // Mineralogical Magazine. - 2013. - V. 77 (5). - P. 2300.

6. Multi-stage mountain building vs. relative plate motions in the Betic Cordillera deduced from integrated microstructural and petrological analysis of porphyroblast inclusion trails / D. G. A. M. Aerden [et al.] // Tectonophysics. - 2013. - V. 587. - P. 188-206.

7. Inter-relationships between deformation partitioning, metamorphism and tectonism / T. H. Bell [et al.] // Tectonophysics. 2013. - V. 587. - P. 119-132.

8. Burg, J.-P. The role of viscous heating in Barrovian metamorphism: thermomechanical models and application to the Lepontine Dome in the Central Alps / J.-P. Burg, T. V. Gerya // J. Metamorphic Geol. - 2005. - V. 23. - P. 75-95.

9. Burg, J.-P. Viscous heating allows thrusting to overcome crustal scale buckling: numerical investigation with application to the Himalayan syntaxes / J.-P. Burg, S. M. Schmalholz // Earth Planet. Sci. Let. - 2008. - 274. - P. 189-203.

10. Gerya, T. Tectonic overpressure and underpressure in litho- spheric tectonics and metamorphism / T. Gerya // J. Metamorph. Geol. - 2015. - V. 33. - P. 785-800.

11. Schmalholz, S. M. Tectonic overpressure in weak crustalscale shear zones and implications for exhumation of highpressure rocks / S. M. Schmalholz, Y. Y. Podladchikov // Geophysical Researh Letters. - 2013. - V. 40. - P. 1984-1988.

12. Tajchmanova, L. Grain-scale pressure variations in metamorphic rocks: implications for the interpretation of petrographic observations / L. Tajchmanova, J. Vrijmoed, E. Moulas // Lithos. - 2015. - V. 216-217. - P. 338-351.

13. Mancktelow, N. S. Tectonic pressure: Theoretical concepts and models / N. S. Mancktelow // Lithos. - 2008. - V. 103. - P. 149-177.

14. Тен, А. А. Динамическая модель генерации высоких давлений при сдвиговых деформациях горных пород (результаты численного эксперимента) / А. А. Тен // Доклады Академии Наук. - 1993. - Т. 328. - № 3. - С. 322-324.

15. Petrini, $K$. Lithospheric pressure-depth relationship in compressive regions of thickened crust / K. Petrini, Yu. Podladchikov // J. Metamorphic Geol. - 2000. - V. 18. - P. 67-77.

16. The problem of depth in geology: When pressure does not translate into depth / E. Moulas [et al.] // Petrology. - 2013. - V. 21(6). - P. 577-587.

17. Schmalholz, S. M. Metamorphism under stress: The problem of relating minerals to depth / S. M. Schmalholz, Y. Y. Podladchikov // Geology. - 2014. - V. 42. - P. 733-734.

18. Ultrafast eclogite formation via melting-induced overpressure / X. Chu [et al.] // Earth Planet. Sci. Lett. - 2017. - V. 479. - P. 1-17.

19. Беляев, О. А. Локальные вариации РТ-параметров тектонометаморфизма в зоне пластического сдвига / О. А. Беляев, Ф. П. Митрофанов, В. П. Петров // Доклады Академии Наук. - 1998. - Т. 361. - № 3. - С. 370-374.

20. Кулаковский, А. Л. Тектонический стресс как дополнительный термодинамический фактор метаморфизма / А. Л. Кулаковский, Ю. А. Морозов, А. И. Смульская // Геофизические исследования. - 2015. - Т. 16. - № 1. - С. 44-68.

21. Likhanov, I. I. Mass-transfer and differential element mobility in metapelites during multistage metamorphism of Yenisei Ridge, Siberia / I. I. Likhanov // Metamorphic Geology: Microscale to Mountain Belts. - London: Geological Society of London, 2018. - Special Publications 478. [S. Ferrero, P. Lanari, P. Gonsalves and E.G. Grosch, eds]. https://doi.org/10.1144/ SP478.11

22. Лиханов, И. И. Железисто-глиноземистые метапелиты тейской серии Енисейского кряжа: геохимия, природа протолита и особенности поведения вещества при метаморфизме / И. И. Лиханов, В. В. Ревердатто, А. Е. Вершинин // Геохимия. - 2008. - Т. 46. - № 1. - С. 20-41.

23. Кианит-силлиманитовый метаморфизм докембрийских комплексов Заангарья Енисейского кряжа / И. И. Лиханов [и др.] // Геология и геофизика. - 2009. - Т. 50. - № 12. - С. $1335-1356$.

24. Лиханов, И. И. Коллизионные метаморфические комплексы Енисейского кряжа: особенности эволюции, возрастные рубежи и скорость эксгумации / И. И. Лиханов, В. В. Ревердатто, П. С. Козлов // Геология и Геофизика. 2011. - T. 52. - № 10. - С. 1593-1611.

25. P-T-t реконструкция метаморфической истории южной части Енисейского кряжа (Сибирский кратон): петрологические следствия и связь с суперконтинентальными циклами / И. И. Лиханов [и др.] // Геология и геофизика. - 2015. - Т. 56. - № 6. - С. 1031-1056.

26. Возраст бластомилонитов Приенисейской региональной сдвиговой зоны как свидетельство вендских аккреционноколлизионных событий на западной окраине Сибирского 
кратона / И. И. Лиханов [и др.] // Доклады Академии Наук. - 2013. - Т. 450. - № 2. - С. 199-203.

27. An alternative model for ultra-high pressure in the Svartberget $\mathrm{Fe}-\mathrm{Ti}$ garnet-peridotite, western gneiss region, Norway / J. C. Vrijmoed [et al.] // Eur. J. Mineral. - 2009. - V. 21. - P. $1119-1133$.

28. Pleuger, $J$. A purely structural restoration of the NFP20-east cross section and potential tectonic overpressure in the Adula nappe (central Alps) / J. Pleuger, Y. Y. Podladchikov // Tectonics. - 2014. - V. 33. - P. 656-685.

29. Лиханов, И. И. Приразломные тектониты Енисейского кряжа. Статья 1: геолого-структурные, минералогические и геохронологические свидетельства полиметаморфизма / И. И. Лиханов, А. А. Крылов, Ж.-Л. Ренье // Вестн. Воронеж. гос. ун-та. - Сер.: Геология. - 2018. - № 2. - С. 56-72.

30. Holdaway, M. J. Application of new experimental and garnet Margules data to the garnet-biotite geothermometer / M. J. Holdaway // Am. Miner. - 2000. - V. 85. - P. 881-889.

31. $W u, C . M$. Recalibration of the garnet-muscovite geothermometer and the garnet-muscovite-plagioclase-quartz geobarometer for metapelitic assemblages / C. M. Wu, G. C. Zhao //Journal of Petrology. - 2006. - V. 47. - P. 2357-2368.

32. $W u, C$. $M$. Empirical garnet - biotite - plagioclase - quartz (GBPQ) geobarometry in medium- to high-grade metapelites / C. M. Wu, J. Zhang, L. D. Ren // Journal of Petrology. - 2004. V. 45. - P. 1907-1921.

33. Wolfram, S. The Mathematica Book. 5th edn. / S. Wolfram // Champaign IL: Wolfram Media Inc. - 2003. - 544 p.

34. . Contact metamorphism of Fe- and Al-rich graphitic metapelites in the Transangarian region of the Yenisey Ridge, eastern Siberia, Russia / I. I. Likhanov [et al.] // Lithos. - 2001a. V. 58. - P. 55-80.

35. Kohn, M. J. Error propagation for barometers / M. J. Kohn, F. S. Spear // Amer. Miner. - 1991. - V. 76. - P. 138-147.

36. Evidence from $\mathrm{Fe}$ - and Al-rich metapelites for thrust loading in the Transangarian Region of the Yenisey Ridge, eastern Siberia / I. I. Likhanov [et al.] // Journal of Metamorphic Geology. 2004. - V. 22. - P. 743-762.

37. Metamorphic, thermal, and tectonic evolution of central New England / F. S. Spear [et al.] // Journal of Petrology. 2002. - V. 43. - P. 2097-2120.

38. Cutts, $K$. A. Three metamorphic events recorded in a single garnet: Integrated phase modelling, in situ LA-ICPMS and SIMS geochronology from the Moine Supergroup, NW Scotland / K. A. Cutts [et al.] // J. Metamorphic Geol. - 2010. - V. 28. P. 249-267.

39. P-T-t constraints on polymetamorphic complexes of the Yenisey Ridge, East Siberia: implications for Neoproterozoic paleocontinental reconstructions / I. I. Likhanov [et al.] // Journal of Asian Earth Sciences. - 2015. - V. 113. - P. 391-410.

40. Holland, T. J. Non-ideal interactions in calcic amphiboles and their bearing on amphibole-plagioclase geothermometry / $\mathrm{T}$. J. Holland, J. D. Blundy // Contrib. Mineral. Petrol. - 1994. - V. 116. - P. 433-447.

41. Dale, J. Hornblende-garnet-plagioclase thermobarometry: a natural assemblage calibration of the thermodynamics of hornblende / J. Dale, T. Holland, R. Powell // Contrib. Mineral. Petrol. $-2000 .-$ V. 140. - P. 353-362.

42. Massonne, $H$. J. Phengite geobarometry based on the limiting assemblage with K-feldspar, phlogopite, and quartz / H. J. Massonne, W. Schreyer // Contrib. Mineral. Petrol. - 1987. - V. 96. - P. 212-224

43. Kohn, M. J. Two new barometers for garnet amphibolites with applications to southeastern Vermont / M. J. Kohn, F. S. Spear // Am. Miner. - 2000. - V. 75. - P. 89-96.
44. Spear, F. S. NaSi-CaA1 exchange equilibrium between plagioclase and amphibole: an empirical model / F. S. Spear // Contrib. Mineral. Petrol. - 1980. - V. 72. - 33-41.

45. Triboulet, $C$. The (Na-Ca) amphibole-albite-chloriteepidote-quartz geothermobarometer in the system S-A-F-M-CNa-H2O. 1. An empirical calibration / C. Triboulet // Journal of Metamorphic Geology. - 1992. - V. 10. - 545-556.

46. Powell, R. Optimal geothermometry and geobarometry / R. Powell, T. J. B. Holland // American Mineralogist. - 1994. - V. 79. - P. $120-133$.

47. Holland, T. J. An internally consistent thermodynamic data set for phases of petrological interest / T. J. Holland, R. Powell // J. Metamorph. Geol. - 1998. - V. 16. - P. 309-343.

48. Evans, B. W. Phase relations of epidote-blueschists / B. W. Evans // Lithos. - 1990. - V. 25. - P. 3-23.

49. Maruyama, S. Blueschists and eclogites of the world and their exhumation / S. Maruyama, J.G. Liou, M. Terabayashi // Intern. Geol. Review. - 1996. - V. 38. - P. 485-594.

50. Ernst, $W$. G. Tectonic history of subduction zones inferred from retrograde blueschist P-T paths / W. G. Ernst // Geology. 1988. - V. 16. - P. 1081-1084.

51. Природа и модели метаморфизма / В. В. Ревердатто [et al.] // Новосибирск: Изд-во СО РАН. - 2017. - 331 с.

52. Крылов, А. А. Геохимия, возраст протолита и метаморфизма высокобарических тектонитов Енисейского кряжа: связь с формированием палеоазиатского океана / А. А. Крылов, И. И. Лиханов // Вестн. Воронеж. гос. ун-та. - Сер.: Геология. - 2017. - № 1. - С. 49-60.

53. Лиханов, И. И. Геохимические и геохронологические свидетельства раннего этапа эволюции палеоазиатского океана на западной окраине Сибирского кратона / И. И. Лиханов, С. В. Зиновьев // Геохимия. - 2018. - Т. 56. - № 2. - C. $120-134$.

54. Powell, $R$. Calculating phase diagrams involving solid solutions via non-linear equattions, with examples using THERMOCALC / R. Powell, T. J. B. Holland, B. Worley // Journal of Metamorphic Geology. - 1998. - V. 16. - 577-588.

55. Holland, T. J. Mixing properties and activity-composition relationships of chlorites in the system $\mathrm{MgO}-\mathrm{FeO}-\mathrm{Al} 2 \mathrm{O} 3-\mathrm{SiO} 2-$ H2O / T. J. Holland, J. Baker, R. Powell // Eur. J. Mineral. 1998. - V. 10. - P. 395-406.

56. A new thermodynamic model for clino- and orthoamphiboles in the system Na2O-CaO-FeO-MgO-A12O3-SiO2-H2O-O / J. F. Diener [et al] // J. Metamorph. Geol. - 2007. - V. 25. - P. 631-656.

57. Green, E. An order-disorder model for omphacitic pyroxenes in the system jadeite-diopside-hedenbergite-acmite, with applications to eclogitic rocks / E. Green, T. Holland, R. Powell // Am. Mineral. - 2007. - V. 92. - P. 1181-1189.

58. Holland, T. Activity-composition relations for phases in petrological calculations: an asymmetric multicomponent formulation / T. Holland, R. Powell // Contrib. Mineral. Petrol. 2003. - V. 145. - P. 492-501.

59. White, $R$. W. Progress relating to calculation of partial melting equilibria for metapelites / R. W. White, R. Powell, T. J. B. Holland // J. Metamorph. Geol. - 2007. - V. 16. - P. 511-527. 60. Holland, T. J. Mixing properties and activity-composition relationships of chlorites in the system $\mathrm{MgO}-\mathrm{FeO}-\mathrm{Al} 2 \mathrm{O} 3-\mathrm{SiO} 2-$ H2O / T. J. Holland, J. Baker, R. Powell // Eur. J. Mineral. 1998. - V. 10. - P. 395-406.

61. Coggon, R. Mixing properties of phengitic micas and revised garnet-phengite thermobarometers / R. Coggon, T. J. B. Holland // J. Metamorph. Geol. - 2002. - V. 20. - P. 683-696. 62. Clarke, G. L. The lawsonite paradox: a comparison of field evidence and mineral equilibria modeling / G. L. Clarke, R. 
Powell, J. A. Fitzherbert // J. Metamorph. Geol. - 2006. - V. 24. - P. 715-725.

63. Wei, C. J. Eclogites from the south Tianshan, NW China: petrological characteristic and calculated mineral equilibria in the Na2O-CaO-FeO-MgO-Al2O3-SiO2-H2O system / C. J. Wei, R. Powell, L. F. Zhang // J. Metamorph. Geol. - 2003. - V. 21. - P. 163-179.

64. Тектоно-метаморфическая эволюция гаревского полиметаморфического комплекса как свидетельство проявления гренвильских событий на западной окраине Сибирского кратона / П. С. Козлов [и др.] // Геология и геофизика. 2012. - Т. 53. - № 11. - С. 1476-1496.

65. Hymalayan tectonics explained by extrusion of a lowviscosity crustal channel coupled to focused surface denudation / C. Beaumont [et al.] // Nature. - 2001. - V. 414. - P. 738-742. 66. Ruppel, C. Pressure-temperature-time paths from twodimensional thermal models: prograde, retrograde and inverted metamorphism / C. Ruppel, K. V. Hodges // Tectonics. - 1994. - V. 13. - P. 17-44.

67. Huerta, A. D. The effects of accretion, erosion and radiogenic heat on the metamorphic evolution of collisional orogens / A. D. Huerta, L. H. Royden, K. V. Hodges // J. Metamorph. Geol. 1999. - V. 17. - P. 349-366.

68. Jamieson, $R$. A. Interaction of metamorphism, deformation and exhumation in large convergent orogens / R. A. Jamieson, C. Beaumont, M. H. Nguyen, B. Lee // J. Metamorph. Geol. 2002. - V. 20. - P. 9-24.

69. Лиханов, И. И. Массоперенос при замещении андалузита кианитом в глиноземисто-железистых метапелитах Енисейского кряжа / И. И. Лиханов, В. В. Ревердатто // Петрология. - 2002. - Т. 10. - № 5. - С. 543-560.

70. Математическое моделирование надвига как причины формирования андалузит-кианитовой метаморфической зональности в Енисейском кряже / С. Н. Коробейников [и др.] // Доклады Академии Наук. - 2006. - Т. 408. - № 4. - С. 512-516.

71. Metamorphic evolution of high-alumina metapelites near the Panimba overthrust (Yenisei Range): mineral associations, PTconditions and tectonic model / I. I. Likhanov [et al.] // Geologiya i Geofizika. - 2001. - V. 42. - P. 1205-1220.

\section{Институт геологии и минералогии им. В. С. Соболева СО РАН, Новосибирск}

Лиханов Игорь Иванович, доктор геолого-минералогических наук, профессор, ведущий научный сотрудник

E-mail: likh@igm.nsc.ru

Тел.: 8 (383) 333-02-39

Крылов Александр Александрович, младиий научный сотрудник

E-mail:krylov@igm.nsc.ru; Тел.: 8 (383) 333-02-39

Университет Мугла, Мугла, Туриия

Ренье Жан-Люк, доктор философии, профессор отделения геологической инженерии

E-mail: jean_lucregnier@mu.edu.tr
72. Лиханов, И. И. Аккреционная тектоника комплексов западной окраины Сибирского кратона / И. И. Лиханов, А. Д. Ножкин, К. А. Савко // Геотектоника. - 2018. - Т. 52. № 1. - C. $28-51$.

73. Shi, Y. Two-dimensional modeling of the P-T paths of regional metamorphism in simple overthrust terranes / Y. Shi, C. Wang // Geology. - 1987. - V. 15. - P. 1048-1051.

74. Karabinos, $P$. Thermal structure of active thrust belts / P. Karabinos, R. Ketchman // J. Metamorph. Geol. - 1988. - V. 6. - P. 559-570.

75. Burov, E. Continental plate collision, P-T-t-z conditions and unstable vs. stable plate dynamics: insights from thermomechanical modeling / E. Burov, P. Yamato // Lithos. - 2008. V. 103. - P. 178-204.

76. Faccenda, M. Deep slab hydration induced by bending related variations in tectonic pressure / M. Faccenda, T. V. Gerya, L. Burlini // Nat. Geosci. - 2009. - V. 2. - P. 790-793.

77. $L i, Z$. H. Influence of tectonic overpressure on P-T paths of HP-UHP rocks in continental collision zones: thermomechanical modeling / Z. H. Li, T. V. Gerya, P. Burg // J. Metamorph. Geol. -2010. - V. 28. - P. 227-247.

78. Лиханов, И. И. Р-Т-t эволюция метаморфизма в Заангарье Енисейского кряжа: петрологические и геодинамические следствия / И. И. Лиханов, В. В. Ревердатто // Геология и геофизика. - 2014. - Т. 55. - № 3. - С. 385-416.

79. Likhanov, I. I. Neoproterozoic intraplate magmatism along the western margin of the Siberian Craton: implications for breakup of the Rodinia supercontinent / I. I. Likhanov, M. Santosh // Precambrian Research. - 2017. - V. 300. - P. 315-331.

80. Likhanov, I. I. Blueschist facies fault tectonites from the western margin of the Siberian Craton: Implications for subduction and exhumation associated with early stages of the PaleoAsian Ocean / I. I. Likhanov, J.-L. Régnier, M. Santosh // Lithos. - 2018. - V. 304-307. - P. 468-488.

81. Ernst, $W$. G. Subduction-zone metamorphism, calc-alkaline magmatism, and convergent-margin crustal evolution / W. G. Ernst // Gondwana Res. - 2010. - V. 18. - P. 8-16.

82. Whitney, D. L. Abbreviations for rock-forming minerals / D. L. Whitney, B. W. Evans // American Mineralogist. - 2010. - V. 95. - P. 185-187.

Sobolev Institute of Geology and Mineralogy of Siberian Branch, Russian Academy of Sciences, Novosibirsk

Likhanov I. I., Doctor of Geological and Mineralogical Sciences, Professor, Principal Research Fellow

E-mail:likh@igm.nsc.ru

Tel.: 8 (383) 333-02-39

Krylov A. A., Junior Researcher

E-mail: krylov@igm.nsc.ru

Tel.: 8 (383) 333-02-39

Department of Geological Engineering, Muğla University, Muğla, Turkey

Régnier Jean-Luc, PhD, Professor

E-mail: jean_lucregnier@mu.edu.tr 